\title{
The Importance of Addressing Accepted Training Needs When Designing Electronic Information Literacy Training
}

\author{
Nicole Fahey \\ Shifty01@tpg.com.au
}

Abstract

The rise of the information revolution has led to information becoming a major producer of wealth. This revolution has increased the importance of being able to access and utilise information from a variety of sources, including information published electronically. The Skills.net program was designed to increase electronic- information literacy skills by providing "free or low cost access to training in online services and the Internet for those in the community who are least likely to have access." (Cavill \& Miller, 1998) This study found that the Skills.net program did increase electronic information literacy. However the program did not adequately address the accepted training needs of its participants and therefore was not as successful as it could have been.

Keywords: Electronic-Information-Literacy, Electronic-Information-Poverty, Training needs, Userfocussed evaluation.

\section{Introduction}

The global economy is currently being transformed from an industrial economy into an information driven economy where information is a major producer of wealth. There is a growing importance for individuals to be able to access and interpret information from a variety of sources. (Kling, 1996) If a person is not able to access information they are faced with information poverty.

Information poverty is a relative form of poverty that leads to people being disadvantaged due to their lack of access to all types of information. There are many factors that contribute to information poverty including language, culture, poor English literacy skills, lack of access to telecommunications, the inability to use software and the lack of a recognised need to access electronic information.

As the information economy grows there will be an increased importance to access to electronic information. Those who cannot access electronic information will experience Electronic Information Poverty (EIP). (Fahey, 2000)

In an attempt to reduce EIP many nations have pledged to develop a Global Information Infrastructure, which if achieved will enable universal access to telecommunications. Many programs around the world

Material published as part of this journal, either on-line or in print, is copyrighted by the publisher of Informing Science. Permission to make digital or paper copy of part or all of these works for personal or classroom use is granted without fee provided that the copies are not made or distributed for profit or commercial advantage AND that copies 1) bear this notice in full and 2) give the full citation on the first page. It is permissible to abstract these works so long as credit is given. To copy in all other cases or to republish or to post on a server or to redistribute to lists requires specific permission and payment of a fee.Contact Editor@inform.nu to request redistribution permission. have also implemented programs to improve general literacy skills in their communities such as reading, writing and mathematical skills.

Some Governments and Government agencies, such as the Victorian Government, the Canadian National Literacy Secretariat, the UK established National Council for Educational Technology and the Singapore Ministry for Education have implemented Electronic Information Literacy programs 
(EIL). (Miller, 1997) These EIL programs aim to increase a person's ability to use electronic means to extract and apply information.

The Victorian Government and Multimedia Victoria (MMV) designed the Community Skills and Networking Program (Skills.net) to address the first objective of the Victoria 21: Into the Information Age policy to develop a multimedia skilled community (Multimedia Victoria, 1999).

Skills.net's purpose was "to provide free of charge or at a low cost access to training in online services and the Internet for those in the community who would otherwise not have access." (Cavill \& Miller, 1998)

The Skills.net program attempts to reduce the widening gap between information rich and poor individuals by providing participants with training and access to computing facilities, thus allowing them to develop some degree of EIL.

Information literacy is described by Charles McClure as "the ability to locate, process, and use information effectively regardless of delivery mechanisms and the type of format in which the information appears; that is, to be literate, one must be literate with both print and electronic formats." (McClure, 1994) The term EIL used throughout this study relates closely to McClure's definition. However EIL only requires literacy in information presented in electronic formats.

This study discusses the ability of Skills.net training to address accepted training needs, and increase participants EIL.

\section{Research on EIL Training Needs}

Although information literacy is extensively discussed in information systems, education and librarianship literature there has been no specific definition of the exact skills required to achieve EIL.

In their report titled, 'Essential Skills for Information Literacy' (WLMA, 1996), the Washington Library Media Association (WLMA) outlined what they identified as essential skills for information literacy.

The WLMA guidelines on skills for information literacy were used to assess whether Skills.net addressed accepted training needs and provided participants with the skills required to become literate in electronic information.

The three WLMA information skills used in this assessment were chosen because they could be directly related to the Web searching and email skills taught by Skills.net. These skill areas are discussed below.

1. Construct strategies for locating information.

Skills.net attempted to enhance participants' strategies for locating information by providing them with knowledge of additional information resources including the Web and email.

2. Locate and access information.

Skills.net training aimed to enable the location and accession of information via Internet searching and email.

3. Evaluate and extract information.

This skill relates to the participants ability to identify whether information obtained is suitable to their need. Extraction of the information may simply be the ability to read and assimilate the information. However in this study extraction of information will relate to the participants ability to access information via electronic sources and locate it again for future use. Some of the methods which may be used to extract information are downloading, bookmarking and printing. 
Three of Kirk and Todd's (in Booker, 1993) guidelines for underpinning information literacy programs, were used to evaluate the ability of Skills.net to meet user needs throughout the design, development and delivery stages of training.

1. Information literacy is relative to the individual, a particular need and the situation of the individual. Therefore Skills.net training should be sensitive to participants needs.

2. Planning and development of the information literacy programs will be based on needs as determined by the users, not defined by the organisation.

3. Program evaluation needs to be evaluated in terms of users' needs, and the benefit and satisfaction derived.

\section{Research Objectives}

This research aimed to determine if Skills.net training increased participants EIL while addressing accepted training needs.

In order to determine the success of the Skills.net project and identify some underlying issues affecting its success a major research question was developed as well as a set of sub questions to answer specific subissues. The formal research question is as follows:

\section{Does Skills.net training Empower Users?}

This question identifies whether Skills.net training meets participants EIL training needs by addressing a set of sub-questions.

The sub questions below focus on whether Skills.net training addresses accepted EIL training need while increasing participants EIL.

- Does Skills.net address accepted needs for training?

- Do Skills.net trainers believe they are achieving their goals of training?

- Do Skills.net participants think they are achieving their goals through Skills.net training? Are they satisfied with the skills they are taught?

\section{Skills.net Program Overview}

Skills.net was provided with five million dollars by MMV to be spent over three years in order to create a network of more than one hundred self-sustainable projects across Victoria. These projects originally aimed to provide forty thousand people with the skills and resources they need to understand and use the Internet. (Cavill \& Miller, 1998) The Skills.net network currently consists of three hundred and three projects across Victoria, which have provided training to over 76293 participants. (Skills.net, 2002)

The Skills.net participants receive training from Leader Projects, which are provided with one hundred thousand dollars to train one thousand participants, or General Projects, which receive ten thousand dollars to train one hundred participants. Both types of projects are meant to provide five hours of training in the use of online technology, as well as, ten hours of access to the Internet for each participant. Original Skills.net projects known as pilot projects were only required to provide two hours of online training and ten hours of Internet access.

All applicants for Skills.net training must complete a survey, which asks the following.

- Do you have access to Internet services? 
- Did you have access to Internet for 5 hours or more over the last six months?

- Do you have a multimedia computer at home, which has at any stage been connected to the Internet? If the applicant answers yes to any of the above questions they may not eligible for Skills.net training.

\section{Skills.net Training Goals}

The training goals developed by MMV and VICNET suggest that all projects should provide training in Web browsing, email, downloading files and creating Web pages.

According to a prior evaluation of the quantity of training delivered by Skills.net, the most common format for the five-hour training is an introduction to the Internet, surfing and browsing the Web, an introduction to email and sending and receiving email (Cavill \& Miller, 1998).

However there is general agreement amongst the projects that they can not cover this amount of training in the time allowed. (Cavill \& Miller, 1998) Therefore the projects have altered the training time and / or the type of training delivered in an attempt to meet participants' needs. However, the trainer's perception of participant's needs may have differed from the participant's actual needs.

\section{Research Methods Used}

Robson states that "the research strategy or strategies, and the methods or techniques employed, must be appropriate for the question that you want to answer." (Robson, 1993)

In order to appropriately answer the main thesis question and its sub-questions, it was necessary to implement the multiple case study research method and two separate data collection techniques. The primary data collection technique used was the survey. The survey was used to collect necessary quantitative data about Skills.net participants EIL skills levels before and after training. It also investigated participants' goals from the training.

From the 412 surveys successfully mailed to respondents 140 useable surveys were returned. This gave the survey a total response rate of $33.98 \%$.

The second data collection method used was a semi-structured interview. The interview technique was used to assess the perceived needs and goals of the Skills.net trainers. This method enabled the collection of qualitative data relating to whether Skills.net addresses accepted needs for information literacy training. This research method also allowed the researcher to gain insight into the background and culture of the organisation.

\section{Results by Cases}

This section describes the results of the cases on an individual basis. However there were some Australian Bureau of Statistics (ABS) observations which impact on the results of all cases. These observations were:

- The likelihood that an adult was an Internet user decreased as age increased. (ABS, 2000)

- Adult males were slightly more likely than adult females to have been Internet users. (53\% compared to $47 \%)(\mathrm{ABS}, 2000)$

- Adults residing in metropolitan areas were more likely to have accessed the Internet than adults residing outside of metropolitan areas. (52\% compared to 44\%) (ABS, 2000). Melbourne's statistical divi- 
sion had 217 ISP's servicing 830,000 subscribers. All other statistical divisions in the State had 68 ISP's servicing 217,000 subscribers (ABS, 2001).

\section{Case One}

\section{Background of organization}

Case One was situated in a large rural community within the Barwon region. According to the ABS the Barwon region had only 5998 access lines to the Internet. (ABS, 2001) Therefore people in this region were only moderately likely to have access to the Internet.

Case One was a well equipped and resourced learning centre largely focused on training teachers in IT skills before it received Skills.net funding. The Skills.net funding enabled them to bring forward by three years their long-term plan to extend training to the broader community. (Cavill \& Miller, 1998)

Case One was one of the pilot Leader Projects and as such was given funding to provide training for 1000 participants. The Skills.net training provided by this organisation consisted of an initial three-hour training session and nine hours of self guided access to Web and email technologies. The training session was an hour longer than Skills.net requirements to allow adequate coverage of the course requirements.

\section{Background of trainer}

The primary trainer at this case had been a trainer for five years and had experience in teaching computer applications such as MS Word, MS Office and Internet applications. They did not undertake any teacher training provided by VICNET because it was not available at the time, however they had received some in-house training some time before Skills.net training began.

\section{Demographics and sample size}

Of the groups studied this Case had trained the largest number of participants and therefore was sent the largest amount of surveys. Of the 216 surveys successfully sent 79 useable responses were returned, with the response rate being $36.57 \%$. This section explains the demographic composition of the people from this location that returned the survey.

\section{Participant training needs}

The trainer at this location found that the training needs of participants varied according on what they needed to use their skills for and participants with a reason to use the technology took up the training with the most enthusiasm.

At this case $47.69 \%$ of participants undertook training to develop computing skills, while $38.46 \%$ participated to explore a new interest.

\section{Age}

Over fifty-five percent of the trainees surveyed at Case One were aged between 36-55 years. In 1998 the ABS reported that $29 \%$ of people aged between $40-54$ years were likely to have had access to the Internet. (ABS, 1998) By November 2000, 52\% of adults within that age group had access. While access figures are increasing the participants at this course are still only likely to have had moderate access to the Internet compared with younger age groups. 


\section{Gender}

Over seventy percent of those surveyed at this location were women.

\section{Satisfaction with training}

Case One was less satisfied with the training they received with few participants claiming to be very satisfied with the course. They were significantly less satisfied than other groups with teaching support, reliability of equipment and course content, although they were more satisfied with the ten hours of Internet access provided.

\section{Summary}

Case One reported moderate skills levels compared to the other cases. Based on age, region and gender statistics Case One were likely to have a moderate level of access to the Internet compared with the other cases studied.

Overall Case One were less satisfied with Skills.net training than other cases. This lack of satisfaction may have been a result of the short (three hour) duration of this training course. To rectify this problem Skills.net now provide at least five hours of training to all participants.

This case felt that the Skills.net designed training areas were slightly less important than the other groups studied. Although they were more satisfied with the with the Internet access provided than the other groups.

\section{Case Two}

\section{Background of organisation}

Like Case One, Case Two was a pilot Leader Project required to provide training to 1000 participants. However Case Two differed from the other cases studied because it was not established before Skills.net funding was granted. This case was funded as a 'start up project' to service a small rural community in the Western Victorian region and was the result of a joint partnership between local Government and the local University. This case was the least likely to have access to the Internet as in 2001 the region had a mere 1113 access lines to the Internet.

Case Two's vision was "to facilitate the uptake and use of multimedia technology and the development of multimedia skills in the region by all sectors of the community and develop opportunities for establishing a multimedia industry through providing hands on experience, training and use of multimedia technology in a non-threatening, flexible and professional environment." (personal communication with Case Two trainer, 1999)

This case provided ten hours of training to its participants in the form of five two-hour sessions, which allowed them to provide more training than other organisations adhering to Skills.net guidelines.

\section{Background of trainer}

The primary trainer at this organisation had worked as a teacher for 13-14 years and had several formal qualifications in this area. Due to their knowledge of curriculum development and design they were employed as the Project Facilitator and as such played a large role in developing the curriculum taught at this venue. 
Although this trainer had no previous specific information technology teaching experience they had experience at teaching music-related technology.

\section{Demographics and sample size}

Case Two was sent 132 surveys and returned 44 useable responses, giving a response rate of $33.33 \%$. This section describes the demographic features of those from Case Two who returned the survey.

\section{Participant training needs}

Case Two's trainer provided anecdotal evidence to support that most of his pupils came to the course because they had a specific need to use the technology, "to email family members overseas or research a hobby".

However $45.95 \%$ of participants undertook training to develop computing skills, while $37.84 \%$ participated to explore a new interest.

\section{Age}

Almost seventy percent of those surveyed at Case Two were between the ages of 56-75 years at the time they were surveyed. According a 1998 ABS survey only $7 \%$ of people aged over 55 years accessed the Internet in the 12 month period ending in November 1998. That figure had increased to $19 \%$ by November 2000 . However this age group is still the least likely to have access to the Internet.

\section{Gender}

Like Case One, the majority of survey respondents were women. However there was a slightly more even distribution with only $62.79 \%$ of respondents being female.

\section{Satisfaction with training}

Overall Case Two respondents were moderately satisfied with the training they received. In general the satisfaction levels reported by this group fell between those of Case One and Case Three.

\section{Summary}

Case Two respondents consistently reported lower skill levels than the other groups before and after training. This lack of skills was expected as this group were the least likely to access the Internet based on their age, region and gender statistics.

The only exceptions were in the areas of Internet searching, email, and Internet history, where the groups reported skill levels very similar to those of Case One. Apart from feeling less skilled than the other groups. This case viewed the majority of training areas as moderately important. Although they perceived Internet searching, Internet history and downloading as less important than other groups.

\section{Case Three}

\section{Background of organisation}

Case Three was a General Project, which conducted training from a community centre in the Melbourne metropolitan region. This Case began conducting Skills.net training in early March 1998. However since the community centre's inception in 1973 they have aimed to provide programs to enhance social justice, 
access and equity to its community. Case Three also attempt to provide lifelong learning opportunities to all individuals regardless of age, gender, race or disability. (Motivating Philosophy, 1999)

Case Three provided five hours of online training and ten hours of access to it's participants as outlined in the Skills.net guidelines. However they were flexible and would alter the course content to suit participant needs.

Being from the Melbourne metropolitan area this case had 111,661 access lines to the Internet and were the most likely case to have access to the Internet. (ABS, 2001)

\section{Background of trainer}

The Skills.net trainer at this location was employed on a sessional basis to deliver Skills.net and Adult Literacy training. Like Case Two the trainer at this location had significant teaching experience in areas other than information technology. Although the trainer had no formal information technology training experience or qualifications they had been incorporating the use of information technology into their literacy teaching for some time.

\section{Demographics and sample size}

Case Three had the smallest number of trained participants to survey, as it was a General Project and was only required to train 100 Skills.net participants. Therefore only 64 surveys were sent to this location and only 17 useable responses were returned. The response rate from this case was lower than the other cases at $26.56 \%$, and the trainer of this case suggested that this might be a result of the high Non-English

Speaking Background (NESB) population at this venue. The section below explains the demographic features of the survey respondents from this case.

\section{Participant training needs}

According to the Case Three trainer the participants at this location wanted to receive training that allowed them to access other people online for social purposes.

Just over forty-one percent of the participants at this location reported that they wanted to explore a new area of interest. While 25\% wanted to develop computer skills, $16.67 \%$ wanted to prepare for study and $16.67 \%$ had "other" reasons to attend.

\section{Age}

Case Three had the youngest population of all the cases surveyed, with over forty percent of respondents aged between 26-45 years. In 1998, 40\% of Australian's aged between 25-39 years were likely to have had access to the Internet. In 2000 this figure rose to $64 \%$ therefore this group was the most likely to have access of the groups studied.

\section{Gender}

This case differed from the other two studied because $58.82 \%$ of survey respondents were male. This was the most likely case to access the Internet in terms of gender.

\section{Satisfaction with training}

This case reported high satisfaction with the training delivered, with significantly higher perceived satisfaction with their teacher and the course content. 


\section{Summary}

Case Three was the most satisfied case studied. In pre-training and post-training categories Case Three respondents considered themselves slightly more skilled in most areas than the other locations. These results were consistent with the ABS findings that this group should have had more access to Internet due to their age, region and gender.

Case Three participants also placed higher importance on most of the training areas than the other groups, which may have been because they had more of an idea of what to expect from training as they were more experienced at using computers.

\section{Summary of Findings}

\section{Does Skills.net Address Accepted Needs for Training?}

The Skills.net programs design, development and delivery was analysed and compared to the guidelines for successful information literacy training by WLMA and Kirk and Todd. To address the WLMA guidelines the training had to enable students to construct strategies for locating, accessing, evaluating and extracting information.

\section{Constructing strategies for locating information}

Skills.net addressed this guideline by providing participants with knowledge of information resources including the Web and email. Once participants had knowledge about how these information resources could help them locate information, they could include the use of these resources into their information gathering strategies.

\section{Locate and access information}

The program addressed this area by providing training in skills, which enabled access to information by using the Web and email. The training also provided students with the ability to refine and narrow Web searches to allow them to locate the most relevant information for their needs.

\section{Evaluate and extract information}

The training enabled participants to evaluate and extract information. The ability to evaluate information was beyond the scope of this course, however Skills.net teaches participants how to extract suitable information for future use. Although the amount of training given on information extraction differed between Skills.net groups some methods taught included bookmarking, downloading / saving and printing.

\section{Information literacy is relative to the individual, a particular need and the situation of the individual}

In order to meet the guidelines established by Kirk and Todd Skills.net training had to demonstrate a user orientation to the design, development and delivery of their training.

Therefore Skills.net training needed to be sensitive to participants needs. The trainers recognised the importance of participants needs and attempted to taylor the course to meet these needs. However, Skills.net training was designed to teach a standard set of skills to training participants and therefore did not allow a great deal of flexibility to enable trainers to meet individual's needs. 


\section{Planning and development of information literacy programs will be based on needs as determined by the users, not defined by the organisation}

Skills.net was not successful in this area because the training program was designed on the basis of user needs determined by MMV and VICNET. There did not appear to be any prior studies by these organisations that identified a set of user needs to be addressed. Therefore it is likely that these organisations based the training, on needs of participants from other training courses or their own perceived needs.

As a result of the training needs being defined by MMV and VICNET several proposed training areas such as creating Web pages were far too advanced for participants. Also, participants did not view some areas such as the history of the Internet as relevant. Therefore trainers were forced to redesign the training to suit participants' requirements, creating inconsistencies in training between the projects.

\section{Program evaluation needs to be evaluated in terms of users' needs, and the bene- fit and satisfaction derived}

Although a prior evaluation of Skills.net recommended investigation into the satisfaction of participants (Cavill \& Miller, 1998) until this study, no such evaluation of user needs, benefit or satisfaction has been undertaken. Therefore Skills.net training was unsuccessful in this area. Skills.net appears to be achieving mixed success in its ability to meet accepted needs of training. While the program is fairly successful in achieving relevant WLMA guidelines for teaching information literacy, the training did not meet user needs adequately enough to be successful in terms of the Kirk and Todd guidelines.

\section{Do Skills.net Trainers believe they are achieving Their Goals of Training?}

The cases studied had different mission statements and slightly different training goals, however all trainers believed that their organisation was successful at achieving its goals through the provision of Skills.net training. It must be noted that this section measures the perceptions of the trainers in this regard, and these perceptions may differ from reality.

Case One believed they were successful because they seemed to meet most of VICNET and MMV's training targets while providing training to the broader community. Case Two met their goals by providing training to those in the broader community who were potentially disenfranchised by not having access to the Web and email. Case Three provided training to individuals regardless of age, gender, race or disability. This organisation exceeded its aims of Skills.net training and was successful at achieving most of VICNET and MMV's training goals.

\section{Do Participants Think They Are Achieving Their Goals Through Skills.Net Training? Are They Satisfied With The Skills They Are Taught?}

The most frequently chosen reasons for undertaking Skills.net training were to develop computer skills or explore a new area of interest. Again it is important to note that the findings in this area were based on the perceptions of users.

It appears that Skills.net training is successful at developing computer skills because most of the participants perceived themselves as more skilled after completing the training. Therefore it is inferred that participants met their goals in this area.

The ability of Skills.net to enable participants to explore a new area of interest is somewhat more difficult to determine, due to a lack of specific questions relating to this area. 
Overall, participants were satisfied with the skills they gained through Skills.net training, even when they did not view the training area as particularly relevant, as in the case of Internet history.

As the satisfaction findings were based on participants perceptions and not skill level testing, it cannot be adequately determined if the skill levels achieved were of a satisfactory standard.

\section{Does Skills.Net Training Empower Users?}

The trainer at Case One saw Skills.net training empower users by providing them with the basic skills necessary to explore their areas of interest. They also believe that Skills.net training empowered users by allowing them to "air their views publicly via the use of email".

Although feeling that empowerment is a difficult thing to quantify the primary trainer at Case Two believed that Skills.net training raised the awareness of participants which could be empowering. The trainer also felt that the degree of empowerment achieved by the training depended on "what people are expecting to get out of it".

The trainer at Case Three believed that Skills.net training empowered people by providing them "with a new set of information communication ... and information gathering possibilities."

The findings in relation to increases in skills and satisfaction with training suggest that Skills.net training did to some degree empower participants by providing them with skills to access a broader range of information resources.

However as the course did not focus closely enough on the needs of its participants it did not provide the degree of empowerment in participants that it could have.

\section{Conclusions}

The Skills.net program was a well-meaning initiative designed to increase the EIL of information poor individuals. However the potential impact of the Skills.net program on increasing EIL was limited due to the failure of the program to adequately address accepted training guidelines.

Skills.net did appear to meet the WLMA guidelines for constructing strategies to locate, assess, evaluate and extract information. However the depth to which these areas were taught and the time spent teaching them varied greatly between the training venues. Therefore it may have not been Skills.net's original design that met user needs in this area, but instead the trainers' modifications to the course structure. These discrepancies made evaluation of the program difficult.

The major failing of Skills.net was that during its development there was no consultation with potential Skills.net participants to determine what their needs were from the training. This meant that the course was developed on what MMV and VICNET believed to be the needs of potential participants and not the actual needs of participants.

However this study appears to demonstrate the effectiveness and applicability of the WLMA and Kirk and Todd evaluation guidelines to aid in the development, implementation and evaluation of EIL training programs. Results from the study appear to indicate that Skills.net participants want strategies for locating, extracting and evaluating information concurring with the WLMA guidelines.

The findings of the study also imply that Skills.net would have been more effective if it had taken into account the Kirk and Todd guidelines and focussed on user needs during its design, development, implementation and evaluation. Although developing an effective EIL course design was outside the scope of this evaluation it would be worthwhile for Skills.net (MMV and VICNET) to adhere to the accepted 
guidelines while developing future EIL training courses. This would ensure that the course design is as effective as possible at meeting user needs while improving EIL.

\section{Acknowledgments}

This paper was first published in Marshall, S., Taylor, W., \& Macpherson, C. (eds.) (2002) Proceedings of IT in Regional Areas Conference 2002 - Using IT: Make IT happen. Central Queensland University Press, Rockhampton, Australia.

Thanks also to the Informing Science 2001 conference as portions of this material have been previously published in the Proceedings of the Informing Science 2001 Conference.

I would like to thank to the Skills.net coordinator, trainers and participants for their contributions to the research.

I would also like to thank Marie van der Klooster, John Lamp, my boyfriend, friends, family and workplace for providing me with continued support.

\section{References}

Australian Bureau of Statistics. (1998). Use of the internet by householders. Canberra: AGPS.

Australian Bureau of Statistics. (2000). Use of the internet by householders. Canberra: AGPS.

Australian Bureau of Statistics. (2001). Internet activity. Canberra: AGPS.

Booker, D. ed. (1993). Information literacy, the Australian agenda: Proceedings of a Conference. Adelaide: University of South Australia Library.

Cavill, M. \& Miller, S. (1998). Report to Multimedia Victoria. Evaluation of the community skills and networking (Skills.net) program. Melbourne: CIRCIT.

Fahey, N. (1999). An investigative report into client empowerment and the Skills.net project. Deakin University [online] Available at: http://www.skills.net.au/download/BCHthesis.pdf [4/8/2000].

Kling, R. ed. (1996). Computerization and controversy: Value conflicts and social choices. 2nd Edition. USA: Academic Press.

McClure, C. (1994). Network literacy: A role for libraries. Information technology and libraries. 13(2). pp.115-125.

Miller, S. (1997). International approaches to skills development in the use of information and communication services. Vol. 15. Melbourne: CIRCIT.

Motivating Philosophy (1999). Retrieved 17 June 1999 from http://home.vicnet.net.au/ dukest/aboutduk.htm\#motivating\%20philosophy

Multimedia Victoria. (1999). Available at: http://www.mmv.vic.gov.au/ Accessed: [5/6/99].

Robson, C. (1993). Real world research: A resource for social scientists and practitioner-researchers. Blackwell Publishers.

Skills.net (2002). Skills.net Website. [online] Available at: http://www.skills.net.au/ . Accessed: [25/5/2002]

Washington Library Media Association Online (1996). Essential skills for information literacy. Available at: http://www.wlma.org/Instruction/wlmaospibenchmarks.htm Accessed: [13/11/98]. 


\section{Biography}

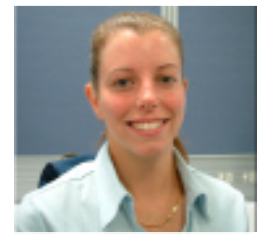

Nicole Fahey is an IT professional with experience in application and web design, development and training.

Nicole has had a consistent interest in issues surrounding information literacy, information poverty and the digital divide since undertaking research in the area in 1998, which led to her B. Com (Hons), at Deakin University Australia. Nicole is keen to promote the importance of training communities to become information literate and speaks frequently on the need for information literacy training. 